Antonov I.A.

DOI: 10.25108/2304-1730-1749.iolr.2018.56.29-51

\title{
Moral essence of the criminal procedural activity
}

\begin{abstract}
An abstract legal analysis of law is fraught with the danger of identifying its prescriptions with the reality, which removes the problem of optimizing of legal regulation aimed to ensure conformity of the law enforcement practice to prevailing ideas of morality and justice. The natural development of this approach was a study of the conditions for effectiveness of law and law enforcement, among which, in addition to purely legal components, social factors took their place.
\end{abstract}

An exceptional role of the state and law in a life of modern society naturally predetermines both the theoretical and practical significance of the problems related to state and legal organization and regulation of social processes. One of the most important directions of this activity is an activity on establishing and ensuring the law and order that corresponds to international standards and international norms in field of protection of human rights and freedoms, democratic principles, declared by the Constitution of Russian Federation, and the moral norms. It cannot be underestimated an importance of law and order in life the both a whole society and a man. The law and order is the basis, an integral attribute of rule-of-law state. The notion 'law and order' itself shows that this order, which based on the law, i.e. the order, determines the scope of rights and freedoms of citizens, and the scope of rights of a state, and also, which is more important, their correlation. All these rights are ensured by law enforcement activities of special state bodies.

\footnotetext{
- Antonov Igor Alekseevich - Doctor of Law, Professor, Professor of the Department for human rights, law enforcement activity, criminal law and process of juridical faculty of Pskov State University, Pskov city, Russia. E-mail: docantonov@yandex.ru
} 
Keywords: criminal procedural activity; humanization of legal relationships; rights and freedoms of man and citizen; law enforcement activity; Code of Criminal Procedure of Russian Federation; criminal process; law and order.

At the present stage of development of Russian society and the state, when there is a radical reforming of legislation in all spheres of life and human activity, the issues of reorganizing the system of law enforcement bodies and improving their activities aimed at humanizing legal relations come to the fore. Judicial legal reform, which has been continued in Russia more than twenty years, has outlined the main directions of reforming of the Russian law enforcement system aimed to real protection of rights and freedoms of man and citizen, following of which, an issue on improving of moral principles in activity of states bodies and officials, who carrying out the criminal proceedings, becomes more actual; since during production on criminal cases, the most acute incursion into the sphere of constitutional rights and freedoms of an individual is possible.

One cannot but agree in this connection with the opinion in the legal literature that law is a historically conditioned social form and a measure of the humanization of society. The social essence of law, its ultimate goal is to achieve real unity of people on the basis of freedom and equality. Hence, a criterion of evaluation of specific legislation, law and order and law enforcement activity should be considered humanism and principle of human unity. Specific legislation, law and order and law enforcement activity is legal if they assist to further human unity and humanization of man and society's life [3, p. 24].

Namely rights and freedoms of man and citizen, their legislative implementation and protection are the necessary condition for operation all systems - political, economic, legal, and social. In this connection, currently, the rights and freedoms of man and citizen are the most important factor to determine the purpose, content, forms of law enforcement activity of the state bodies. Law 
enforcement activity has only in that case the legal nature when this activity is carried out on the basis and frames of law and when protection and ensuring the rights and freedoms of an individual are the goal and its essence.

A.I. Aleksandrov completely justly indicates that the state of legal lawfulness in the state interconnected with harmonization of the interests of an individual, society and state, is the measure of ensuring their safety, and also acts as a certain indicator of legitimacy and legality of an authority that issues normative acts $[1, p$. 8].

In this relation it is not exception such kind of law enforcement activity like criminal procedural one. In compliance with international standards of protection of the rights and freedoms of an individual in area of administration of justice on criminal cases, and also with principles enshrined in the Constitution of Russia, new Code of Criminal Procedure of Russian Federation of 2001 indicated on exceptionally human rights oriented purpose of modern Russian criminal proceedings. This is completely justly. Recognition of man, his rights and freedoms as supreme value of society and state, declaring of man as a central figure of law enforcement activity, and protection of his rights and freedoms as the goal of criminal procedural activity became a requirement of time and legal reality.

In this connection, namely from position of protection of the rights and freedoms of man and citizen we should research in the frames of the present work the moral content of law enforcement activity in entire and moral essence of criminal procedural activity, as a kind of law enforcement activity, in particular. Whereas, main accent should be made in issues of moral improvement of criminal procedural activity, in the frames of which, the rights and freedoms of an individual are subjected to the greatest derogation.

It is not in vain the criminal process is called the most politicized branch of law. In addition, a content of criminal procedural legislation depends on the state legal ideology. The striking example of this acts the modern stage of fight of our 
state against terrorism and Federal law "On amending the Code of Criminal Procedure of the Russian Federation" of 22 April 2004, which postponed a time of bringing the charge to a person detained in custody, and suspected in commission of terroristic crimes up to 30 days [7]. In this regard is noteworthy the words of A.I. Aleksandrov: "Criminal process must not be a commodity. It is bad, when an official of law enforcement bodies takes a bribe for releasing from responsibility of a culprit, but it is more terrible when he takes money for bringing to responsibility of obviously innocent man. The system of criminal procedural norms should be such in order to exclude designed criminal cases regardless who ordered it. In legal state the criminal repressions cannot be a subject of purchase and sale" [1, p. 7].

Research made by A.F. Koni at the turn of 19-20 centuries has encouraged the study of these issues. The scientist wrote that moral principles were belonged in future the major role in studying of conditions and environment of criminal process. It began the time together history and dogma to light those manifold issues that appeared in each stage of the process, which were subjected to resolving according to essential requirements of the moral law - this non scripta, sed nata lex (Latin, not written, and natural law). Now, the forms of court proceedings were more or less strongly established everywhere. A view on value, suitability and expediency of various judicial institutions was determined the same way. Certainly, under the influence of temporary recklessness, the legislation can step back and come back to obsolete and out-of-use institutions, however it cannot seriously encroach on fundamental principles of justice - publicity, verbal, immediacy and free evaluation of evidence. These acquirements of mankind were bought too expensive by centuries suffering and delusion so that it would be easy and for long time to part with them.

At the same time, it is unlikely that mankind will soon come up with a form of court that can replace a jury trial with lasting success, or find it possible to dispense with an adversarial beginning. Therefore, in all likelihood, in the future 
there will be only a partial improvement of some branches of criminal process and clarification of the technique for producing a criminal investigation. But next to this sophistication of technology is to go the development of true and broad philanthropy in court, equally distant from the mechanical leveling of separate individuals, and from the callousness of techniques, and from the alien true goodness of the flabbiness of a will in protection of the public order. Then, the main attention will be paid with full justification to the study of moral principles of criminal process - and the center of gravity of a doctrine on judicial proceedings will be transferred from the course of process to the ethical and socio-legal activity of a judge in all its branching [4, p. 78-79].

One cannot forget the thoughts of A.F. Koni. Nowadays, it is important to continue his ideas, embody in life his undertakings, developing moral beginnings of criminal proceedings. These issues should be systematically made (following M.S. Strogovich, N.A. Komarova, N.A. Sidorova and T.N. Moskalkova), especially taking into account the adoption of new criminal procedural law - CCP of Russian Federation, which norms should be verified in matching with moral and legal criteria of the criminal procedural activity, in order that the both criminal procedural legislation would meet requirements of moral law and regulated by it the activity would designed on the beginnings of freedom, justice and humanism.

Law enforcement activity of the state, and also the lawfulness as an indispensable condition of this activity, as rule, in such branches of juridical knowledge like administrative law, educational subjects 'Law enforcement bodies', 'Judicial system', 'Prosecutor's supervision' and some others. Whereas, we can with satisfactory note that the last time sociological aspect of law enforcement activity and its structural elements attract attention of the more researchers. It has caused, first of all, with desire to determine their real place in social structure of society and political structure of the state, to learn the nature of the law and law enforcement activity onto social reality, on level of moral and 
legal culture in society, to measure the level of real ensuring of the rights and freedoms of man and citizen, protection of law and order.

As it is noted in legal literature "law enforcement is an activity particularly social. Consequently, to understand its nature and essence might be only in context of that social reality, in which it is formed, functioned and developed. By other words, in the broadest sense, the nature and essence of law enforcement activities are determined the both the nature and essence of a man himself and also the way of joint vital activity of people" [3, p. 33].

This approach reflects clear understanding of the fact that abstract and legal analysis of law is inherent with danger of identification its inscriptions with the reality taking off the problem of optimization of legal regulation in purpose of ensuring the conformity of law enforcement practice with the current ideas of morality and justice. Natural development of this approach is to study the conditions of effectiveness of the law and law enforcement, among of which, apart from pure legal components, the social factors took its place [5, p. 9].

Sociological approach helps to realise the social value of the law and law enforcement activity. Their perception in a broad social plane allows seeing better the reformative opportunities of law and legitimacy. Legal categories are stood by one row with such broader notions like democracy, humanism, justice, natural rights and freedoms of man and citizen. Wherein, disclosing the essence and principles of democracy and by Article one of the Constitution of Russian Federation our state declared as democratic. Correspondently, it was also enshrined in other constitutional norms and also guarantees of protection of rights and freedoms of man and citizen (Article two indicated that man, his rights and freedoms are the highest value, and recognition, observance and protection is a duty of the state). In addition, a role of lawfulness and functioning of law enforcement system in the state is evaluated more correct. Against this background, there is formed an understanding of the true social role of the moral 
essence of law enforcement activities in general and of criminal procedural activity as its variety, in particular.

With the system of legal guarantees of democracy and protection of rights and freedoms of man and citizen should be linked not only the law and requirement of principle of lawfulness, but also the most important consequence of implementation of this principle - law and order and condition its ensuring - law enforcement activity of the state.

S.S. Alekseev wrote that law and order is a state of actual ordering of social relationships, expressing real, practical implementation of requirements of lawfulness... Law and order encloses a chain of main socio-political phenomena of field of legal superstructure (law-lawfulness-law and order) [2, p. 235-236]. In order to include law enforcement activity in the chain it is necessary to note that that for operation of the law it is not enough to proclaim a legal norm, no matter how moral content it was filled with, its action is required to be ensured. In this connection, an important role in mechanism of the operation of law belongs to state bodies exercising enforcement, law enforcement activity; these bodies of the states carry out law supporting function. Protection of rights and freedoms of man and citizen should be considered as a final result of this activity the both the legal and moral point of view.

An exceptional role of the state and law in a life of modern society naturally predetermines both the theoretical and practical significance of the problems related to state and legal organization and regulation of social processes. One of the most important directions of this activity is an activity on establishing and ensuring the law and order that corresponds to international standards and international norms in field of protection of human rights and freedoms, democratic principles, declared by the Constitution of Russian Federation, and the moral norms. It cannot be underestimated an importance of law and order in life the both a whole society and a man. The law and order is the basis, an integral 
attribute of rule-of-law state. The notion 'law and order' itself shows that this order, which based on the law, i.e. the order, determines the scope of rights and freedoms of citizens, and the scope of rights of a state, and also, which is more important, their correlation. All these rights are ensured by law enforcement activities of special state bodies.

Wherein it should paid especial attention to determination of necessary scope and bounders of the state and legal regulation of social processes in legal state. One cannot look at extension and strengthening of the state and legal regulation like on resolution of all problems. One cannot forget that "the tendency to detailed regulation and control of all social relations is inherent in the police state, and in opposite of legal state this is its distinctive sign" [6, p. 139]. In this connection, it is necessary to determine the bound and scope of state and legal regulation, which corresponds to the legal state, but to police state; it is necessary to restrict the rights and freedoms of man and citizen, his private life from unsubstantiated intervention by state bodies and officials, carrying out criminal procedural activity, in the frames of which this intervention is more sensible. Therefore, the present article devoted to matters of studying of moral principles of criminal proceedings, directed to protection of rights and freedoms of persons, which involved in production on criminal case.

The matters, which linked with understanding of the nature and essence of legal state, law and order, law enforcement activity, have now especial social significance, when Russian state, at last, turned a face to a man. Constitution of Russia declares that a man, his rights and freedoms are the highest value, and their observance and protection is duty of the state (Article 2). A man should be a goal, but not the means of activity of all state bodies. Rights and freedoms of man and citizen, their protection and safety should be corner-stone of all activity of the state and its bodies, should be its moral content. 
Undoubtedly, in final, everything is depended on resolution of such fundamental moral and legal issue as a problem of interrelation of citizen and the state (in person of state bodies); which is same age like society and state. Various approaches were suggested for its resolution, however their studying shows that it might be distinguished and dwelt upon the two main ones.

The first approach is based on priority of the state (of whole) over a man, person (of part). In this self-sufficing whole the part plays subordinated role and is only the means of achievement its purposes. Accordingly, the resolution of the problem is seen in the fact that the state just absorbs its parts, and thereby, as it were, removes all differences and contradictions existing between them. The second one proceeds from the priority of man in relation to the state. In such context a role of the state is to ensure the rights and freedoms of man in their extension. With this approach, in principle desirable and correct, there is a danger that a person becomes self-sufficient element in relation to the state. The interests of the state are, however, essentially ignored or even denied.

It becomes understandable that "the absolutisation of any of these approaches leads to a dead end, and in practice results in extremely difficult social cataclysms. Absolutisation of the role and purposes of the whole leads to suppression of man (citizen), to violation his rights and freedoms, to his deformation, and finally, to deformation of the whole itself. In turn, absolutisation of the rights and freedoms of person (citizen) leads to violation of the rights of the whole, is often resulted with arbitrariness and anarchy that leads to destroying of the whole, and consequently, to deformation of person (citizen) himself, which cannot exist fully out of society (state)" [3, p. 14]. In this regard, it is necessary to solve the problem of ordering, balance of relations between a person and the state. Undoubtedly, research on the philosophy of law, natural law, and moral and legal criteria for evaluating state activity should help in this. 
From the legal point of view a problem of balance of the rights and freedoms of man and citizen, the rights of a state and bounds of self-restraint is quite decidable. Law is the real form of existence and functioning of the right in a society. Consequently, the both balance rights and bounds of self-restraint can be established with law. However, one cannot forget that freedom, justice, humanism are the fundamental, essential characteristics of the law. Namely they should be put in the basis of designing of law and order and organization of law enforcement activity in the basis of morality, designing of morally-contained national legislation.

\section{References}

1. Aleksandrov A.I. Ugolovnaya politika i ugolovnyi protsess v rossiyiskoyi gosudarstvennosti: istoriya, sovremennost', perspektivy, problem [Criminal policy and criminal process in the Russian statehood: history, modernity, prospects, problems] / Pod red. V.Z. Lukashevich [Ed. by V.Z. Lukashevich]. Vol. 1. S. Petersburg, 2003, 562 p.

2. Alekseev S.S. Obschaya teoriya prava [Common theory of law]. Vol. 1. Moscow, 1981, $361 \mathrm{p}$.

3. Gutseriev Kh.S., Salnikov V.P. and others. Chelovek i pravookhranitel'naya deyatel'nost'. [Man and law enforcement activity] / Pod red. V.P. Salnikov [Ed. by V.P. Salnikov]. S. Petersburg, 2000.

4. Koni A.F. Izbrannye trudy i rechi [Selected works and speeches]. Sost. I.V. Potapchuk [Compiled by I.V. Potapchuk]. Tula, 2000, 550 p.

5. Kurs sovetskogo ugolovnogo protsessa. Obschaya chast' [Course of soviet criminal process. Common part]. Pod red. A.D. Boykova i I.I. Karpetsa [Ed. by A.D. Boykov and I.I. Karpets]. Moscow, 1989, 640 p. 
6. Kistyakovskyi B.A. V zaschitu prava [In protection of law]//Vekhi. Iz glubiny. Moscow, 1991, 606 p.

7. Rossiyskaya gazeta [Russian newspaper]. 2004. 27 Apr. 